\title{
Telework and health effects review
}

\author{
Aida Isabel Tavares* \\ CEISUC, Centre for Health Studies of the University of Coimbra, Portugal
}

Received: April 3, 2017

DOI: $10.5430 /$ ijh.v3n2p30
Accepted: June 30, 2017

Online Published: July 11, 2017

\begin{abstract}
Telework is an increasingly popular flexible working arrangement. The aim of this article is to describe the features that characterize telework. The advantages and disadvantages of teleworking are outlined, as well as its effects on the health of the worker. The method used was a literature review. The outputs of this search show that in general, empirical evidence favours a positive association between telework and worker health. However, there are also negative impacts on health such as stress and depression. The overall conclusion is that telework is likely to yield more good than bad for individual health.
\end{abstract}

Key Words: Telecommuting, Teleworking, Workers, Health

\section{INTRODUCTION}

Teleworking originally started to become popular since the oil crisis of the 1970s when it was realized that if one in seven urban commuters would work from home, then the US would have no need to import oil. So it became evident that work flexibility could result in benefits for organization and for employees. The term "telecommuting" was introduced by Nilles ${ }^{[1]}$ in the mid-1970s.

While the US term for "home-working" is telecommuting, in Europe, it is termed telework. But the terms to express telework are varied and include work-at-distance, off-site work or even remote work. The idea behind all of them is the same, it is the work to be done in a place and not a place where the worker has to go. ${ }^{[2]}$

The European Framework Agreement on Telework of 2002 defines telework in Article 2: "Telework is a form of organising and/or performing work, using information technology in the context of an employment contract/relationship, where work, which could also be performed at the employer's premises, is carried out away from those premises on a regu- lar basis". Although this definition is broad, it does capture the main idea behind telework, which is work flexibility in space and time.

Flexible working became an opportunity for workers to improve their work, family and social life by decreasing work constraints and gaining autonomy over their own affairs. The boundaries between working and non-working time have become flexible and adjustable to the needs of people at different stages in life: study time, family, aging or simple individual preferences. Telework is therefore a decisionmaking tool regarding working hours and adapting them to the needs and preferences of workers (and the demands of the employer).

Telework, as a form of flexible work arrangement, became more and more significant in the late 1990s as the use of home computers, laptops, mobile phones and sophisticated telecommunications software become an everyday work tool.

The number of workers teleworking was still increasing in the last decade. In the US, the growth was around $80 \%$ between 2005 and 2012 and in this last year teleworkers represented

*Correspondence: Aida Isabel Tavares; Email: aitavar@gmail.com; Address: Avenida Dias da Silva, 165, 3004-512 Coimbra, Portugal. 
$2.6 \%$ of the total employee workforce (about 3.3 million people, excluding the self-employed and unpaid volunteers) who considered home as their primary place of work. ${ }^{[3]}$ The number of employees using telework in the US between 2005 and 2012 is $1,819,355$ and 3,268,525 respectively, and the percentage of those employees in the total workforce is $2.6 \%$ in 2012.

Telework is less often used in the European labour market than it is in the US. Some figures show that at the beginning of the 21 st century, full-time telework was carried out by just over $1 \%$ of the working population (around 1.5 million people) and occasional teleworking was a slightly more common (5\% of workers) ${ }^{[4]}$ More recently, it has been estimated that around $3 \%$ of EU workers are teleworking from home. ${ }^{[5]}$

But the telework arrangement is not found consistently in European countries. While the UK has around $10 \%$ of employees doing telework for at least $25 \%$ of the time, in Portugal and Italy the figure is only $2 \%$, as can be seen in Table $1 .{ }^{[6]}$ The countries with the highest proportion of teleworkers are Denmark, Netherlands, Sweden and Luxembourg. ${ }^{[5]}$

Table 1. Percentage of teleworkers in Europe

\begin{tabular}{llllllllllllllllll}
\hline \% work force & UK & L & FIN & NL & A & B & DK & S & E & F & IRL & D & EL & P & I & EU15 \\
\hline At least 25\% time & 10 & 9 & 8 & 7 & 6 & 6 & 6 & 5 & 4 & 4 & 4 & 4 & 2 & 2 & 2 & 5 \\
All the time & 2 & 3 & 1 & 1 & 3 & 2 & 1 & 1 & 3 & 2 & 1 & 0 & 1 & 1 & 0 & 1 \\
\hline
\end{tabular}

Telework is naturally more often found in certain professions and usually associated with highly skilled white collar jobs. In Europe, $7 \%$ of telework is done by managers and $13 \%$ by professionals or technicians (for instance, statisticians or financial brokers). ${ }^{[5]}$ In fact, the sectors where telework is most often found are education, with $12 \%$ of teleworkers, financial and other services ( $8 \%$ ), and the public administration with $3 \%$ of teleworkers. ${ }^{[5]}$

Nowadays it can be seen that working hours have extended into the evening and night and to weekends. So, they have become more flexible in a 24-hour society. The 3rd EU Survey on Working Condition showed that what is termed normal working hours (meaning from 9.00-18.00 on week days) have become the exception rather than the rule. Employed people with this traditional rigid pattern of working hours represented only $27 \%$ of all the employed people in the survey. Analysis of the survey data shows a positive correlation between flexibility (under individual discretion and control) and better health outcomes. However, results also show that longer working hours are associated with stress, fatigue, sleeping problems, and anxiety. ${ }^{[6]}$ The Sixth European Working Conditions Survey recently concluded that overall, according to the job quality indices, teleworkers work more intensively but have more autonomy at work and better career prospects. ${ }^{[5]}$

The overall aim of this paper is to consolidate the information on the topic of telework and health, and also to provide a structured text for a wide range of interested readers. For this, the main features of telework have been reviewed and its associated trade-offs are described, in particular, the health effects for workers. Telework tasks and jobs require a certain individual profile to ensure success. Additionally, the

Published by Sciedu Press characteristics of telework tasks and workers' profiles help to explain the advantages and disadvantages of telework to the worker, as well as the effects on health.

The method used in this work was a literature review, so this article has been written in a narrative non-exhaustive format, without evaluation of the articles, rather than a format which could include quality assessment and tabular synthesis. There are two systematic reviews on this topic in the literature. One is by De Croon et al., ${ }^{[7]}$ and the other by Joyce et al. ${ }^{[8]}$ The first systematically reviews how the office concept (including telework) can influence a worker's job demands, job resources, short- and long-term reactions (including health). The second reviews the health effects of flexible work conditions on employees and their families.

\section{METHOD}

The method used is a general literature review as classified by Grant et al. ${ }^{[9]}$ This provides a review of the recent and current literature and covers a wide range of subjects in varying degrees of completeness and comprehensiveness. This form of literature review is usually presented in a narrative form, as it is here.

Google Scholar was used to search for articles, using the key words "telework + health", "telecommuting + health", "telework + health + effects or impacts", "telecommuting + health + health or impacts", between April and June 2015 and updated between 10-12 June 2016. The selection of the articles was based on the general principal that the reference should be a specialised report, an empirical analysis or a review. The articles proposing a conceptual or theoretical framework have not been analysed, nor have those which did not have a clear focus on telework. 
The search of the set of articles used here was not comprehensive, and the quality of the work contained in them was not assessed. A summary of the selected references is included, based on the aspects covered in this article.

\section{Results}

\subsection{Telework features and teleworkers}

Professions that rely on telephones, computers and other communication technology devices are strongly related to the potential performance by telework. Some professions have intrinsic features that make them better suited to being performed through telework, such as management and specialised professionals. The tasks performed under a telework contract are usually described as follows: $:^{[10,11]}$

- information based and portable,

- their performance requires high level of concentration,

- their performance involves a high degree of autonomy,

- can be planned in advance and performed at varying times of the day,

- creating, processing and disseminating information,

- results in measurable output such as written reports, statistical figures, software, etc.

This last characteristic plays an important role when contracts are drafted between the firm and the worker. The sustaining theory that models the relationship between employee and employer is the well-known "agency theory", which states that interests of the two parties may be aligned by optimal contracts, which mostly depend on the performance of the employees. ${ }^{[12,13]}$

The demanding nature of the tasks that can be performed through telework suggests that not everyone is suited to it. Empirical evidence profiles the successful teleworker as someone with the following personal characteristics: ${ }^{[14-16]}$

- Self-motivation: skilled at setting routines and meeting deadlines.

- High level of job knowledge and skills: enough knowledge of their position to facilitate working and solving problems independently.

- High performance: solid performers, although it is important for some top performers to remain in the office at least part of the time to mentor co-workers.

- Independence and confidence: because there is less exposure to supervision and feedback, individuals should have the ability to make independent decisions.

- Comfortable with solitude: because of the isolation, individuals with less need for social interaction are well suited to telecommuting arrangements.

- Time management and organisational skills: because of limited daily demands or checks, individuals should have the ability to schedule and organise their work to meet deadlines.

- Concentration: highly focused and able to handle potential distractions.

- Strong communication skills: more effort is needed to stay in touch with managers and co-workers, providing them with necessary information and updates while working away from the office setting.

- Trustworthiness and reliability: individuals are accountable for getting the job done to the same extent as if they were being supervised in the office setting; mutual trust is an essential element of a telework arrangement.

These personal characteristics are very relevant to the way people design strategies to deal with the obstacles of teleworking and perform the tasks, especially without damaging their health.

\subsection{Pros and cons of telework}

The advantages and disadvantages of telework, from the teleworker perspective, have been identified by several authors ${ }^{[14,17-26]}$ and others have reviewed or listed them. ${ }^{[2,15,27,28]}$ These are summarised in Table 2.

Table 2. Advantages and disadvantages of telework

\begin{tabular}{ll}
\hline Advantages & Disadvantages \\
\hline $\begin{array}{l}\text { Better balance of home and } \\
\text { work life }\end{array}$ & $\begin{array}{l}\text { Blurring of boundaries between } \\
\text { work and home time and overwork } \\
\text { autonomy }\end{array}$ \\
$\begin{array}{l}\text { Reduction in commuting time } \\
\text { Increased productivity }\end{array}$ & $\begin{array}{l}\text { Social isolation } \\
\text { Lack of support, inadequate } \\
\text { equipment }\end{array}$ \\
$\begin{array}{l}\text { Higher morale and job } \\
\text { satisfaction }\end{array}$ & Career progression or promotions \\
Avoidance of office politics & Resentment from colleagues \\
\hline
\end{tabular}

Teleworkers spend less time travelling, commuting and away from home. They can thus use this time to be with the family and enjoy a better balance of home and work life. However, the blurring of boundaries between work and home time may create family conflict or erode rest time.

Homeworking increases people's flexibility and autonomy. Teleworkers can often choose their hours of work, enabling them to take advantage of off-peak hours at the supermarket, the gym, and administrative offices so as to work in their most productive part of the day, or even to take on another job. Nevertheless, homeworking is right next to the breakfast table and so teleworkers tend to work long and continuous hours, even when they are sick. This is called presenteeism. Working when unwell impacts the speed and quality of the 
recovery and well-being of the worker, not to mention the effect on the quality of the work.

Teleworkers tend to be more productive than their counterparts in traditional offices because they have fewer interruptions and distractions, can work longer hours, make better use of high productivity moments, and enjoy flexibility when planning work schedules. Despite this potential for higher productivity, teleworkers often face lack of technical support and may have inadequate equipment which prevents them from achieving the desired productivity. Nevertheless, this disadvantage can be mitigated nowadays because internet access is provided via optical fibre cables, thereby ensuring high speed and reliability. Additionally, computer anti-virus software prevents problems of losing work and the use of cloud computing systems allows sharing software and files.

Higher morale and job satisfaction are common among teleworkers, who tend to be highly motivated to prove that this choice is better and more successful. However, being away from the central office may have a negative impact on their career progression because they tend to be overtaken by other workers who are better positioned for lobbying. However, the lobbying by the work colleagues will happen no matter what, they are focused on their goals and lobbying is part of their tasks in the office.

Another advantage of homeworking is the avoidance of office politics. This is mainly about relationships targeting power, influence and careers; it consumes time and effort. Some people may prefer to focus on performance and care less about office politics. The other side of this can be the social isolation that workers may feel because they spend long hours alone without social interaction and the resentment of colleagues, who cannot be home-workers.

Today's communication technology is built on high connectivity instruments and processes, easy and reliable information sharing, easy and cheap communication, and our sophisticated computers and mobile phones make social interaction and work output presentation easy, no matter where people are located. ${ }^{[29]}$ Therefore, from our perspective, the disadvantage of being absent from the main office is not really relevant nowadays.

\subsection{Health issues associated with telework}

Telework has recognised effects on health. The overall effect on health is neither well known nor consensual. ${ }^{[27,30]}$ Most empirical work reports positive and negative effects but there has been little analysis of the trade-offs associated with telework and its net benefits or net costs.

The methodological difficulty of measuring trade-offs makes it hard to determine if telework benefits outweigh the cost

Published by Sciedu Press to workers' health. Nonetheless, apparently there is sufficient evidence to infer that the benefits override the health problems. Noting the historical and statistical evolution of telework, which has been around now for more than 40 years and is still expanding, it seems that it generates a net benefit for individuals (and organisations). If telework had mainly had a negative impact on the health (and job satisfaction) of workers, then eventually they would have lost the willingness to do it ${ }^{[31]}$ and telework would have tended to disappear.

As Michael Marmot stated: "depriving people of control over their lives... is indeed damaging to their health", ${ }^{[32]}$ so it is likely that telework benefits health more than it damages it because it helps people to be better able to control their life. In fact, some evidence seems to indicate that telework has net benefits for employees; ${ }^{[28,33-35]}$ in other words, "telecommuting is likely more good than bad for individual". [36]

\subsubsection{Identified health problems}

The health problems associated with telework can be grouped into four categories: musculoskeletal problems, isolation and depression, stress and overwork and others. These are now described in more detail.

\section{Musculoskeletal problems}

Working long hours with a computer, usually at home, is associated with a static and constraining posture, repetitive movements, extreme positions of the forearm and wrist, and with long periods of continuous work. These are risky behaviours that contribute to the development of musculoskeletal problems in the neck, shoulders, wrist, hand and lumbar regions. ${ }^{[2,27,37]}$ Moreover, teleworkers do not socialise with colleagues and so they do not take health breaks, which are important for musculoskeletal relaxation, and they spend long hours seated, without appropriate breaks. ${ }^{[38,39]}$

\section{Isolation and depression}

The nature of telework means that teleworkers do not establish a social work relationship with their colleagues, especially those in the office. Being far from the workplace added to the long, continuous working hours can induce feelings of loneliness and isolation. ${ }^{[15,20,22,33,36,40]}$ It has even been suggested that teleworkers should spend at least $20 \%$ of their work time in the office to prevent such feelings of isolation. ${ }^{[41]}$

\section{Stress and overwork}

Today stress is strongly correlated with cardiovascular diseases, type 2 diabetes and poor mental health (particularly depression), which is why it has our full attention today. ${ }^{[22]}$

Stress is an emotional response to pressure suffered due to the context in which a person is living or working and over 
which they have no control. While the immediate effects of stress hormones may be beneficial, long term exposure to stress accustoms the body to the high level of hormones, which generates a negative effect on the human body. Stress is caused by stressors and it is revealed by changes in physiological and psychological behaviour. Stressors are triggers of stress and they include all influences (job and non-job related) that affect someone at work, such as work tasks, deadlines, equipment, organisational and procedural regulations, spatial-temporal and physical conditions. ${ }^{[43]}$

Stress-response theory provides a theoretical framework for the linkages between work flexibility (as in telework) and health. ${ }^{[44]}$ This flexibility includes the schedule and the location, which are the main aspects of telework. The linkages between work flexibility and health are mainly twofold. On the one hand, flexibility reduces exposure to some stressors since workers are better able to control their lives, reduce family conflict and improve family-work balance. Moreover, telework flexibility provides resources to enable workers to respond to stressors and so to prevent negative impacts of stress on health. ${ }^{[34]}$ On the other hand, flexibility creates more stress due to family responsibilities, blurred work-home life boundary and, potentially, family conflict. ${ }^{[45,46]}$ Additionally, telework creates job stress related to factors such as overwork, tight deadlines, intense and long working hours, inability of switch off and less time to rest. ${ }^{[20,46-48]}$ It is also related to poor mental health, exhaustion and impaired state of health. ${ }^{[17,28,31,40]}$

\section{Other health problems}

Other health problems can be identified and associated with flexible work conditions. These health problems include metabolic, cardiovascular, and gastrointestinal disorders. Metabolic disorders include hypertension, high cholesterol and higher fasting blood sugar levels. ${ }^{[4,50]}$ Moreover, cancer is likely to be a negative effect of certain health imbalances created by work flexibility, and women's reproductive function is also potentially affected. ${ }^{[49]}$

\subsubsection{Health benefits}

A number of health benefits are generated with telework for people choosing this alternative work arrangement.

Several empirical works have found positive and beneficial effects on teleworkers' health. Benefits accrue from reducing the stress ${ }^{[42]}$ of the daily home-work commute, ${ }^{[30,50,51]}$ having greater schedule flexibility and a better work-life balance, ${ }^{[20,28,34,52,53]}$ better life control, and enhanced job satisfaction. ${ }^{[17,54-58]}$

The effects on health outcomes such as sickness and impairment seem to occur less often with the choice of telework. ${ }^{[34]}$
Moreover, working from home provides an environment that favours better concentration, less noise, fewer interruptions, more privacy (which open-office spaces often destroy), better air quality (which may be dubious in the traditional office), all of which contribute to workers' health. ${ }^{[22]}$

\section{CONCLUSION AND FUTURE RESEARCH}

Telework is a flexible work arrangement which has been increasingly adopted worldwide. Workers seem to be willing to choose this form of work since it improves their working and social life by easing work constraints and yielding gains in autonomy over their own affairs. Telework has become a solution for people at different stages in their life, when they may be studying, bringing up a family, or growing older, or it can simply match their individual preferences by letting them decide when and where to work.

Telework tasks have particular features which require certain personality traits for the job to be done successfully. Moreover, these features contribute to defining the pros and cons, in particular the health effects, of doing a job under telework conditions. Workers face a cost-benefit trade-off when doing telework. There is a general view that it results in a net benefit for workers and in a positive effect on their health. This is mainly because there is less stress and a better workfamily life balance. This trend in the empirical evidence may be more significant in today's world. The reason for this trend may be that some of the potential disadvantages of telework, mainly related to workers not being in the main office, are strongly mitigated by the sophisticated communication technology readily available today.

The main limitation of this literature review is the potential for the selection of the articles to be subjective, even though Google Scholar provides the most cited articles and exhaustive lists of references. The informative nature of this text and the main goal defined do not require a systematic review of the literature. This article is therefore contributing with a well-structured and well-condensed text with information obtained from a wide literature review on telework and its health effects.

Future research may continue studying the effects of telework on teleworkers and on health utilization. Another line of potential research could focus, firstly, on the relationship between the workers' personality traits and their health outcomes, and secondly, on the relationship between the workers' performance and their health outcomes, particularly, those associated with depression and stress.

Finally, research is needed to reassess the relevance of some telework disadvantages and health effects associated with isolation and lack of social interaction, because nowadays there 
is a high speed communication technology, with diverse and wide connectivity options, easy and trustworthy information sharing, easy and cheap communication, and broad access to sophisticated computers and mobile phones.

\section{CONFLicts OF INTEREST Disclosure}

The author declares no conflicts of interest.

\section{REFERENCES}

[1] Nilles JM. Telecommunications and organizations decentralization. IEEE Transactions on Communications Com. 1975; 23: 1142-1147. https://doi.org/10.1109/TCOM.1975.1092687

[2] Baruch Y. Teleworking: benefits and pitfalls as perceived by professionals and managers. New Technology Work and Employment. 2000; 15(1): 34-49. https://doi.org/10.1111/1468-005X.00 063

[3] Global Workplace Analytics, 2012 [cited 2015 Aug 4]. Available from: http://globalworkplaceanalytics.com/telec ommuting-statistics

[4] The European Working Conditions Survey, 2015 [cited 2015 Aug 4]. Available from https://www.eurofound.europa.eu/surv eys/european-working-conditions-surveys

[5] Eurofound . Sixth European Working Conditions Survey - Overview report, Publications Office of the European Union, Luxembourg. 2016.

[6] Paolli P, Merllié D. Third European Survey on Working Conditions 2000. Dublin: European Foundation for the Improvement of Living and Working Conditions, Loughlingstown, Co. 2001.

[7] De Croon E, Sluiter J, Kuijer PP, et al. The effect of office concepts on worker health and performance: a systematic review of the literature. Ergonomics. 2005; 48: 2, 119-134. PMid: 15764312. https://doi.org/10.1080/00140130512331319409

[8] Joyce K, Pabayo R, Critchley JA, et al. Flexible working conditions and their effects of employee health and wellbeing. The Cochrane Library. Cochrane Database Systematic Reviews. 2010; 17(2): CD008009.

[9] Grant MJ, Booth A. A typology of reviews: an analysis of 14 review types and associated methodologies. Health Information and Libraries Journal. 2009; 26: 91-108. PMid: 19490148. https: //doi.org/10.1111/j.1471-1842.2009.00848.x

[10] Doherty ST, Andrey JC, Johnson LC. The economic and social impacts of telework. Paper presented at the Telework: The new workplace of the 21st Century symposium; 2000; New Orleans.

[11] Van Horn CE, Storen D. Telework: Coming of age? Evaluating the potential benefits of telework. Paper presented at the Telework: The new workplace of the 21st Century symposium; 2000; New Orleans.

[12] Gray P. The virtual workplace. OR/MS Today.1995; 22(4): 22-26.

[13] Eisenhardt KM. Agency theory: An assessment and review. Academy of Management Review 1989; 14(1): 57-74.

[14] Pyoria P. Managing telework: risks, fears and rules. Management Research Review 2011; 34(4): 386-399. https://doi .org/10.1 108/01409171111117843

[15] Bailey DE, Kurland NB. A review of telework research: findings, new directions and lessons for the study of modern work. Journal of Organizational Behaviour. 2002; 23: 383-400. https : //doi.org/10.1002/job.144

[16] Shilling S. The basics of a successful telework network. HR Focus; 1999; 76(6): 9-11.

[17] Sardeshmukh S, Sharma D, Golden T. Impact of telework on exhaustion and job engagement: a job demands and job resources model.
New Technology, Work and Employment. 2012; 27(2): 193-207. https://doi.org/10.1111/j.1468-005X.2012.00284.x

[18] Jones K. Going home: new technology's impact on remote work engagement. Advances in Business Research. 2010; 1(1): 168-175.

[19] McNall LA, Masuda AD, Nickling JM. Flexible work arrangements, job satisfaction, and turnover intentions: the mediating role of workto-family enrichment. Journal of Psychology. 2010; I44(1): 61-81.

[20] Mann S, Holdsworth L. The psychological impact of teleworking: stress, emotions and health. New Technology, Work and Employment. 2003; 18(3): 196-211. https://doi.org/10.1111/1468-005X. 00121

[21] Hill EJ, Ferris M, Martinson V. Does it matter where you work? A comparison of how three work venues (traditional office, virtual office, and home office) influence aspects of work and personal/family life. Journal of Vocational Behavior. 2003; 63: 220-241. https://doi .org/10.1016/S0001-8791(03)00042-3

[22] Montreuil S, Lippel K. Telework and occupational health: a Quebec empirical study and regulatory implications. Safety Science. 2003; 41: 339-358. https://doi .org/10.1016/S0925-7535(02) 000 42-5

[23] Baruch Y, Nicholson N. Home sweet work: requirements for effective home working. Journal of General Management. 1997; 23: 15-30. https://doi.org/10.1177/030630709702300202

[24] Novaco RW, Gonzalez OI. Commuting and well-being. In AmichaiHamburger Y. (Ed) Technology and Psychology Wellbeing. Cambridge: Cambridge Press; 2009. https ://doi .org/10.1017/CB 09780511635373.008

[25] Peters P, den Dulk L, van der Lippe T. The effects of time-spatial flexibility and new working conditions on employeens' work-life balance: the Dutch case. Community, Work and Family. 2009; 12(3): 279-297. https://doi.org/10.1080/13668800902968907

[26] Henke RM, Benevent R, Schulte P. The effects of telecommuting intensity on employee health. American Journal of Health Promotion. 2016; 30(8): 604-612. PMid: 26389981.

[27] Crawford JO, MacCalman L, Jackson CA. The health and well-being of remote and mobile workers. Occupational Medicine (London). 2011; 61: 385-394. PMid: 21921124. https://doi .org/10.109 3/occmed/kqr071

[28] Butler AB, Grzywacz JG, Ettner SL, et al. Workplace flexibility, self-reported health, and health care utilization. Work and Stress: An International Journal of Work, Health and Organizations 2009; 23(1): 45-59. https://doi.org/10.1080/02678370902833932

[29] Pearce II J. Successful corporate telecommuting with technology considerations for late adopters. Organizational Dynamics. 2009; 38(1): 16-25. https://doi.org/10.1016/j.orgdyn.2008.10.002

[30] Steward B. Health trade-offs in teleworking, and exploratory study of work and health in computer home-based working. The Indexer. 2001; 22(3): 142-146.

[31] Weinert C, Maier C, Laumer S. Why are teleworkers stressed? An empirical analysis of the causes of telework enabled stress. In Thomas $\mathrm{O}$ and Teuteberg $\mathrm{F}$ (Eds). Proceedings der 12 International en Tagung Wirtshaftsinformatik. Osnabruck; 2015: 1407-1421. 
[32] Marmot M. The art of medicine, Europe: good, bad, and beautiful. Lancet. 2013; 381: 1090-1091. https://doi.org/10.1016/SO 140-6736 (13)60749-7

[33] Grant CA, Wallace LM, Spurgeon PC. An exploration of the psychological factors affecting remote e-worker's job effectiveness, wellbeing and work-life balance. Employee Relations. 2013; 35(5): $527-$ 546. https ://doi .org/10.1108/ER-08-2012-0059

[34] Casey PR, Grzywacz JG. Employee health and well-being: the role of flexibility and work-family balance. Psychologist-Manager Journal. 2008; 11: 31-47. https://doi.org/10.1080/10887150801963 885

[35] Grzywacz J, Casey P, Jones F. The effects of workplace flexibility on health behaviors: a cross-sectional and longitudinal analysis. Journal of Occupational and Environmental Medicine. 2007; 49(12): 1302 1309. PMid: 18231077. https://doi.org/10.1097/JOM.0b01 3e31815ae9bc

[36] Gajendran RS, Harrison DA. The good, the bad and the unknown about telecommuting: meta-analysis of psychological mediators and individual consequences Journal of Applied Psychology. 2007; 92(6): 1524-1541. PMid: 18020794. https ://doi.org/10.1037/0021 $-9010.92 .6 .1524$

[37] Skov T, Borg V, Orhede E. Psychosocial and physical risk factors for musculoskeletal disorders of the neck, shoulders, and lower back in salespeople. Occupational Environmental Medicine. 1996; 53: 351356. PMid: 8673184. https://doi.org/10.1136/oem.53.5.3 51

[38] Sang K, Gyi D, Haslam C. Musculoskeletal symptoms in pharmaceutical sales representatives. Occupational Medicine. 2010; 60: 108114. PMid: 19812347. https://doi.org/10.1093/occmed/kqp 145

[39] Budworth N. Health risks from teleworking. Croner's Occupational Hygiene Magazine. 1999; 18: 11-18.

[40] Borg V, Kristensen TS. Psychosocial work environment and mental health among travelling salespeople. Work Stress. 1999;13: 132-143. https://doi.org/10.1080/026783799296101

[41] Fairweather NB. Surveillance in employment: the case of teleworking. Journal of Business Ethics. 1999; 22(1): 39-49. https : //doi.org/10.1023/A:1006104017646

[42] Cohen S, Janicki-Deverts D, Miller GE. Psychological stress and disease. JAMA - Journal of the American Medical Association. 2007; 298 (14): 1685-1687. PMid: 17925521. https://doi.org/10.1 001/jama.298.14.1685

[43] Konradt U, Hertel G, Schmook R. Quality of management by objectives, task-related stressors and non-task-related stressors as predictors of stress and job satisfaction among teleworkers. European Journal of Work and Organizational Psychology. 2003; 12(1): 61-79. https://doi.org/10.1080/13594320344000020

[44] Rice VH. Theories of stress and relationship to health. In V. H. Rice (Ed.) Handbook of stress, coping, and health: implications for nursing research, theory and practice (27-45). Canada: Thousand Oaks, Sage; 2000.
[45] Standen P, Daniels K, Lamond D. The home as a workplace: workfamily interaction and psychological well-being in telework.Journal of Occupational Health Psychology. 1999; 4(4): 368-381. PMid: 10526841. https://doi.org/10.1037/1076-8998.4.4.368

[46] Huws U, Podro S. Employment of homeworkers: examples of good practice. Geneve: International Labor Organization - Conditions of work and welfare facilities branch, 1995.

[47] Hartig T, Kylin C, Johansson G. The telework tradeoff: stress mitigation vs constrained restoration. Applied Psychology: an International Review. 2007; 56(2): 231-253. https ://doi.org/10.1111/j.14 64-0597.2006.00252.x

[48] Dimitrova D. Controlling teleworkers: supervision and flexibility revisited. New Technology, Work and Employment, 2003;18(3): 181195. https ://doi.org/10.1111/1468-005X.00120

[49] Costa G. Shift work and health: current problems and preventive actions. Safety Health Work. 2010;1: 112-123. PMid: 22953171. https ://doi.org/10.5491/SHAW.2010.1.2.112

[50] Thomas LT, Ganster DC. Impact of family-supportive work variables on work-family conflict and strain: a control perspective. Journal of Applied Psychology. 1995; 80: 6-15. https://doi.org/10.103 7/0021-9010.80.1.6

[51] Kurland NB, Bailey DE. Telework the advantages and challenges of working here, there, anywhere and anytime. Organization Dynamics. 1999; 28: 53-68. https://doi.org/10.1016/S0090-2616(00 ) $80016-9$

[52] Stephens G, Szajan B. Perceptions and expectations: why people choose a telecommuting work style. International Journal of Electronic Commerce. 1998; 3(1): 70-85. https ://doi.org/10.108 $0 / 10864415.1998 .11518328$

[53] Bloom N, Liand J, Roberts J, et al. Does working from home work? Evidence from a Chinese experiment. Quarterly Journal of Economics. 2015; 130(1): 165-218. https://doi.org/10.1093/qj e/qju032

[54] Wheatley D. Good to be home? Time use and satisfaction levels among home-based teleworker. New Technology, Work and Employment. 2012; 27(3): 224-241. https://doi.org/10.1111/j.14 68-005X.2012.00289.x

[55] Madsen SR. The benefits, challenges, and implications of teleworking: a literature review. Journal of Culture and Religion. 2011; 1 : 148-158.

[56] Golden J, Wiens-Tuers B. To your happiness? Overtime work, worker happiness and satisfaction. Journal of Socio-Economics. 2006; 35 382-397. https://doi.org/10.1016/j.socec.2005.11.039

[57] Wilkes RB, Frolick MN, Urwiler R. Critical issues in developing successful telework programs. Journal of Systems Management. 1994; 45(7): 30-34

[58] Kowalski KB, Swanson JA. Critical success factors in developing telework programs. Benchmarking: an International Journal. 2005; 12(3): 236-249. https://doi.org/10.1108/14635770510600357 